\title{
Uptake of inhaled lead from motor exhaust
}

\author{
A. C. Chamberlain \\ M.A., Sc.D. \\ M. J. HEARD
B.Sc.
}
A. N. B. Stott
M.B., Ch.B

\author{
W. S. Clough \\ B.Sc., Ph.D., F.R.I.C. \\ D. Newton \\ B.Sc., M.Sc.
}

A. C. Wells

Environmental and Medical Sciences Division, A.E.R.E., Harwell

To assess the contribution of lead in motor exhaust to the total uptake of lead it is necessary to know the amount deposited in the lungs, the uptake thence to blood and other tissues, and the rate of excretion from the body. There are reports of experiments in which volunteers have inhaled aerosols of lead oxide or sesquioxide (Kehoe, 1961; Hursh et al., 1969; Booker et al., 1969; Cole and Lynam, 1972) but the physical and chemical characteristics of the particles differed from those of the exhaust aerosol. Blood lead has also been measured in persons with varying degrees of exposure to exhaust lead (Azar, Snee and Habibi, 1972; Jones, Commins and Cernik, 1972) or industrial lead (Williams, King and Walford, 1969). By attaching a radioactive label $\left({ }^{203} \mathrm{~Pb}\right.$, radioactive half-life $52 \mathrm{hr}$ ) to tetraethyl lead (TEL) which is then mixed with petrol and burnt in an engine, we have made a realistic tagged lead exhaust aerosol, and this has been inhaled by volunteers. The retention in the lung, removal to blood, and excretion of the lead have been followed by measuring ${ }^{203} \mathrm{~Pb}$ in the body, in blood and in excreta, using techniques of gamma-ray spectrometry.

\section{Preparation of aerosol}

${ }^{203} \mathrm{~Pb}\left(\mathrm{PbCl}_{2}\right.$, about $5 \mathrm{mCi}$ per batch) was obtained from the Medical Research Council Cyclotron Unit, Hammersmith Hospital. Labelled TEL was synthesized using a Grignard reaction, by a method kindly made available to us by $\operatorname{Dr} \mathrm{A}$. Whittingham. The labelled TEL and an appropriate amount of ethylene dibromide scavenger were added to about $100 \mathrm{ml}$ of lead-free petrol. A minimum amount of lead carrier had to be added in the preparation, but this was reduced as skill was acquired. In the first experiments, the lead : petrol ratio was high (up to $20 \mathrm{~g} / \mathrm{l})$, but later it was reduced to a normal commercial level of $0.5 \mathrm{~g} / \mathrm{l}$. A $67 \mathrm{cc}$ Honda 4-stroke engine was warmed up using normal leaded petrol and then switched to the petrol with labelled TEL. The engine was operated without load at 4000 r.p.m., or under load at 5000 r.p.m. The burning of the tagged petrol took about $10 \mathrm{~min}$ and produced about 400 litre of exhaust which was passed into a 600 litre plastic container previously containing air. To reduce the $\mathrm{CO}$ concentration, an oxidation catalyst ('Hopcalite', Hopkins and Williams Ltd.) mixed with silica gel for improved efficiency was spread on the floor of the container. The CO concentration was measured periodically with Drager tubes, and was reduced below 1000 p.p.m. before inhalation, which took place an hour or more after the engine was stopped. Meanwhile the gases and particles in the exhaust were mixed by natural convection currents in the container. Contact between $\mathrm{CO}$ and the oxidation catalyst was by gaseous diffusion. Samples were drawn through filter papers to monitor the aerosol concentration, and the ${ }^{203} \mathrm{~Pb}$, total lead and total particulate loadings were measured at the time of inhalation. The lead concentration was typically about $6 \mathrm{mg} / \mathrm{m}^{3}$ and total particulate $30 \mathrm{mg} / \mathrm{m}^{3}$. Coagulation resulted in the loss of the smallest $(\sim 0.01 \mu \mathrm{m})$ particles (Fig. 1) but the aggregates of dimensions about $0.5 \mu \mathrm{m}$ were stable, and the rate of loss of aerosol to the floor and walls of the container was only about $10 \% / \mathrm{hr}$ by mass. Electron micrographs of particles sampled from exhaled air showed a more homogeneous structure (Fig. 1). A similar effect was obtained by drawing the usual chain-aggregate type aerosol through a humidifier.

In some experiments the container was exposed to sunlight for about $1 \mathrm{hr}$ so that the aerosol received ultra-violet radiation before inhalation took place.

\section{Inhalation}

The subjects, who were seated at rest, inhaled the 

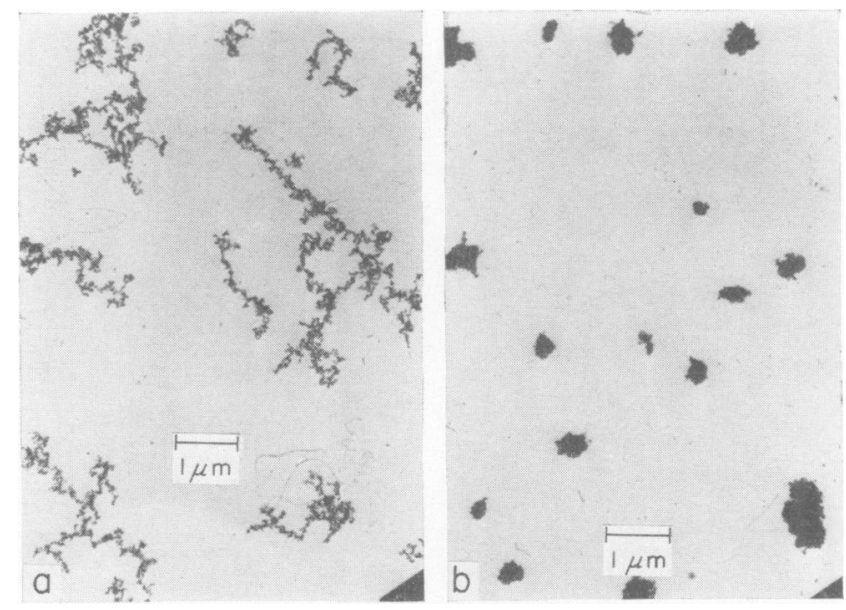

Fig. 1. Electron micrographs of particles sampled from exhaled air. (a) before inhalation, (b) after inhalation.

aerosol through a mouthpiece, and exhaled through a filter to a spirometer. The breathing rate and average minute volume of the subjects were measured. After about ten breaths the subject breathed room air for a short time while the spirometer was re-set. The oxides of nitrogen, hydrocarbons and other components of the exhaust gave a slightly unpleasant taste but caused no distress. The total volume inhaled was 50-200 litre. Typically about $0.5 \mu \mathrm{Ci}$ of ${ }^{203} \mathrm{~Pb}$ was deposited and the radiation dose to the lung was about 2 mrem.

\section{Injection}

Three subjects received intravenous injections of ${ }^{203} \mathrm{~Pb}$, with $0 \cdot 1 \mu \mathrm{g}$ stable lead chloride as carrier, in $20 \mathrm{ml}$ normal saline. This was done primarily to calibrate the whole body counter and also to estimate the proportion of lead entering the blood which remained there after equilibration in the circulation. Three subjects also received injections of their own whole blood incubated at $37^{\circ} \mathrm{C}$ with ${ }^{203} \mathrm{PbCl}_{2}$ in saline for $15 \mathrm{~min}$.

\section{Radioactivity measurements}

All measurements were made using $\mathrm{NaI}(\mathrm{Tl})$ crystals to detect the $279 \mathrm{keV}$ gamma rays of ${ }^{203} \mathrm{~Pb}$. The detectors were generally housed in the large $10 \mathrm{~cm}$ thick lead shield of the Harwell whole-body counter. Whole body activity was measured with an array of six $\mathrm{NaI}$ crystals $15 \mathrm{~cm}$ in diameter and $9 \mathrm{~cm}$ thick.

To follow clearance of activity deposited in the lungs and upper respiratory tract, two $15 \mathrm{~cm}$ diameter detectors viewing the anterior and posterior surfaces of the thorax were fitted with cylindrical collimators. ${ }^{203} \mathrm{~Pb}$ in samples of venous blood (usually $20 \mathrm{ml}$ ), and in urine and faeces (complete daily collections) was also measured by gamma-ray spectrometry. When interference from natural ${ }^{40}$ was significant, the spectrum was resolved into it constituent activities by a computer method o least squares fitting.

All results were corrected for the radioactive deca糔 of ${ }^{203} \mathrm{~Pb}$ (half-life $52 \mathrm{hr}$ ).

\section{Initial deposition in lung}

The activity initially deposited in the subject was assessed in two ways: (i) from the differences between the amount inhaled (concentration in the inhaled air multiplied by the volume breathed) and the amount on the exhalation filter; (ii) from the measurements of whole-body radioactivity. Agreement between the two methods was not always good, and further investigations are being made. However, both sets of results suggest an average of about $40 \%$ immediate retention in the lung, $60 \%$ of the aerosol being exhaled. It is difficult to compare the results of other investigations since the concept of mass median equivalent diameter is not readily applicable to aerosols of the chain aggregate type (Lawther et al., 1972). This is particularly true when, as shown in Fig. 1, the physical characteristics of the particles change while they are in the respiratory tract.

\section{Removal from lung}

The collimated detectors viewing the subject's thorax responded to systemic activity in the chest region as well as to material remaining in the lungs. For some subjects, approximate corrections for this could be calculated from the response of the chest 


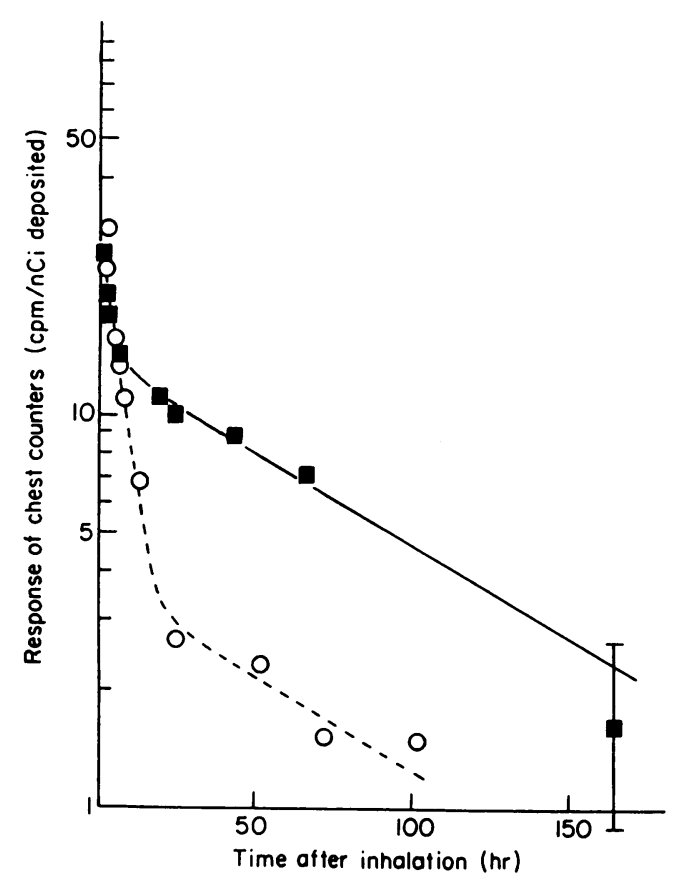

FIG. 2. Response of chest counters corrected for activity in blood. $\square$, irradiated aerosol; $\bigcirc$, non-irradiated aerosol.

counters to systemic activity after injection of ${ }^{203} \mathrm{~Pb}$. Fig. 2 shows the response, corrected in this way, from one subject after inhalation of irradiated and non-irradiated exhaust. In both cases a proportion of the activity was removed from the lung with a half-life of about $6 \mathrm{hr}$. Approximately $90 \%$ of the non-irradiated aerosol was cleared at this rate, the remainder showing a half-life of $\sim 75 \mathrm{hr}$. With the irradiated exhaust, however, the slower clearance phase became apparent after only $\sim 50 \%$ had been removed. Two other subjects showed similar twophase patterns, but with less difference between the irradiated and non-irradiated exhausts.

\section{Uptake by blood}

Figure 3 shows the amount of ${ }^{203} \mathrm{~Pb}$ in blood at various times after inhalation (six subjects, thirteen experiments), injection of ${ }^{203} \mathrm{~Pb} \mathrm{Cl}_{2}$ in saline (three subjects) and injection of tagged red cells (three subjects). The results are derived from measurements of ${ }^{203} \mathrm{~Pb}$ in samples of venous blood, and expressed as the percentage of the total initial body burden, using the estimated blood volume for each subject.

Following inhalation, ${ }^{203} \mathrm{~Pb}$ in blood increased to a maximum at about $50 \mathrm{hr}$, when an average $48 \%$ of the initial lung burden had been transferred to blood. This result, which agrees with previous work (Hursh

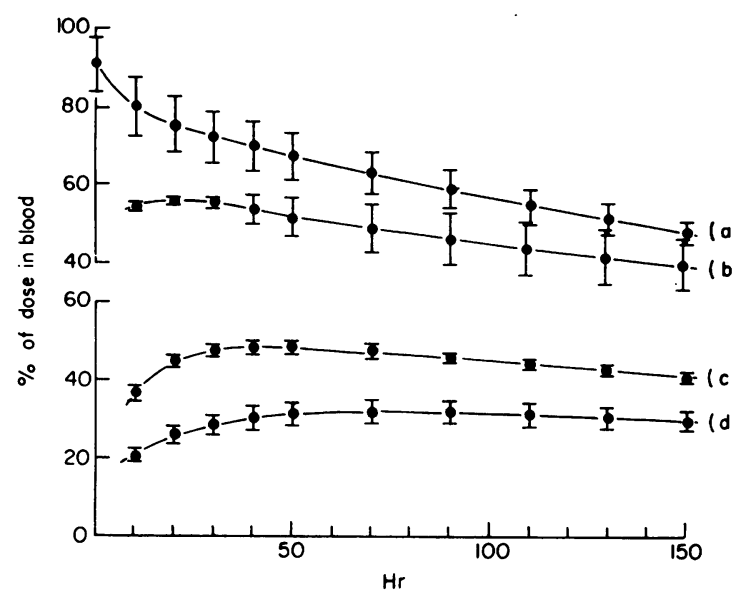

Fig. 3. ${ }^{203} \mathrm{~Pb}$ in blood following inhalation or injection. (a), injections of labelled red cells; (b), injections of saline; (c), inhalations-non-irradiated; (d), inhalations $-\mathrm{U} / \mathrm{V}$ irradiated.

et al., 1969; Booker et al., 1969; Hursh and Mercer, 1970) with ${ }^{212} \mathrm{~Pb}$, was little affected by variations in the TEL : petrol ratio, or by the mode of operation of the engine. Inhalation of exhaust which had beeno irradiated in sunlight (mean of three subjects) gave $32 \%$ uptake to blood. The initial rate of increase in blood lead was consistent with the initial rate of ${ }^{+}$ clearance from the lung.

Venous blood taken about $15 \mathrm{~min}$ after injection of ${ }^{203} \mathrm{PbCl}_{2}$ in saline contained less than half the activity expected if the dose was distributed in the estimated blood volume. Similar results have previously been found with dogs (Stover, 1959) and humans (Hursh et al., 1969; Booker et al., 1969; Hursh and Mercer, 1970) and attributed to a very rapid partitioning of lead between plasma and extracellular fluid. The ${ }^{203} \mathrm{~Pb}$ in blood reached a peak a few hours after injection, at which time the percentage of the dose in blood was similar to that reached after inhalation.

Tests in vitro, confirming other work (Booker et al., 1969; Clarkson and Kench, 1958) showed that $90 \%$ of ${ }^{203} \mathrm{~Pb}$ added in saline solution was removed from plasma to red cells within $15 \mathrm{~min}$, and in venous blood samples no more than $3 \%$ of the ${ }^{203} \mathrm{~Pb}$ was in the plasma. Following injection of ${ }^{203} \mathrm{~Pb}$ which had been incubated with the subject's blood, there was initially nearly $100 \%$ pro rata recovery in blood samples, but thereafter ${ }^{203} \mathrm{~Pb}$ in blood declined and after $100 \mathrm{hr}$ there was little difference between the amount in blood following saline and tagged cell injection. It appears, therefore, that even with incubation before injection ${ }^{203} \mathrm{~Pb}$ is equilibrated between blood and other tissues. 


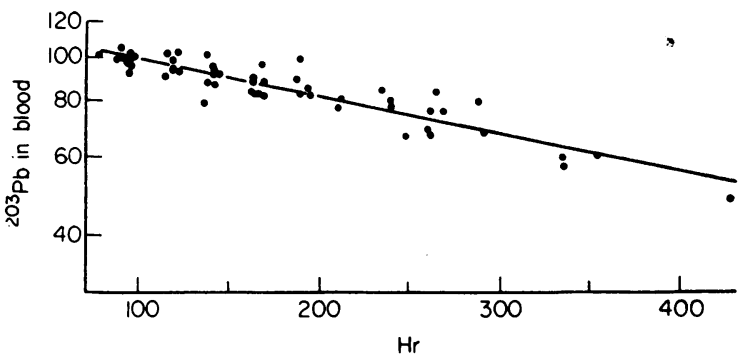

Fig. 4. Blood levels of ${ }^{203} \mathrm{~Pb}$ following inhalation of nonirradiated aerosols (normalised). Half-life $=15 \cdot 3$ days.

From about 3 or 4 days after inhalation, ${ }^{203} \mathrm{~Pb}$ in blood declined with an initial half-life of 15 days. Figure 4 shows the pooled results from six subjects. Radioactive decay of ${ }^{203} \mathrm{~Pb}$ prevented this being followed for more than one biological half-life. Rabinowitz, Netherill and Kopple (1973) gave a subject ${ }^{204} \mathrm{~Pb}$ for 114 days, and measured the concentration of that stable isotope in blood. After the administration stopped. the blood concentration declined with a half-life of 17 days. However, following injection of ${ }^{210} \mathrm{~Pb}$ in dogs, a three-component exponential decay of blood activity was found (Hursh, 1973) and it is unlikely that the 15- to 17day half-life in humans would continue indefinitely.

\section{Excretion}

Excretion after inhalation and injection is shown in Fig. 5. Subjects were followed-up for varying lengths of time, and the points on the upper curves in Fig. 5 are the means of twelve experiments with

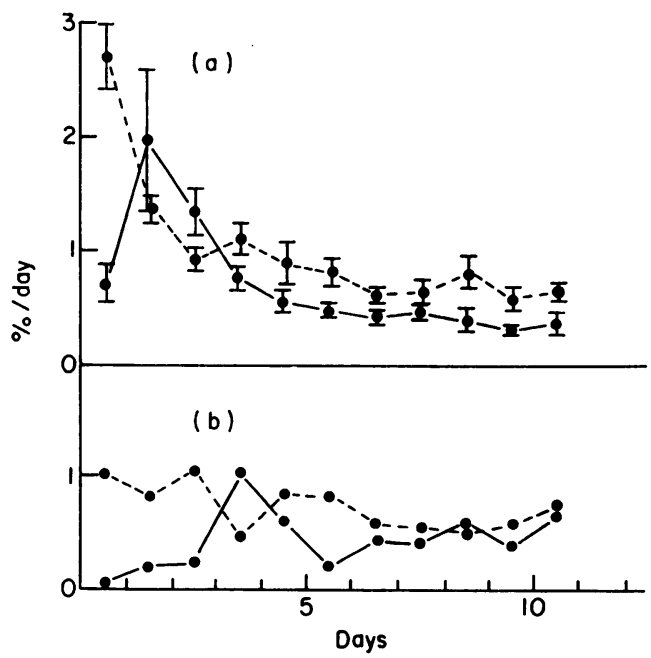

Fig. 5. Excretion of ${ }^{203} \mathrm{~Pb}$ in urine and faeces following inhalation or injection. (a), after inhalation; (b), after injection (labelled red cells); _ _ _ , urine; faeces. six subjects for the first 2 days, reducing to two subjects on days 10 and 11 . The lower curves (injection of tagged cells) refer to one subject only. The faecal excretion of inhaled ${ }^{203} \mathrm{~Pb}$ was only slightly greater than the faecal excretion of injected ${ }^{203} \mathrm{~Pb}$. As about $90 \%$ of ingested lead is excreted in faeces (literature values confirmed by a separate study on three subjects who ingested aerosol on filter paper in the course of the present work), it is evident that only a small fraction of the retained inhaled dose was brought up by ciliary action and swallowed.

Immediately after inhalation and injection, renal clearance (rate of excretion of ${ }^{203} \mathrm{~Pb}$ in urine divided by ${ }^{203} \mathrm{~Pb}$ /unit volume of blood) was high, as in previous work with ${ }^{212} \mathrm{~Pb}$ (Booker et al., 1969). This is attributed to clearance from the plasma during the initial equilibration. The average renal clearance several days after inhalation or injection was 4.3 $\mathrm{ml} / \mathrm{hr}$, compared from example with $4.5 \mathrm{ml} / \mathrm{hr}$ clearance of stable lead measured by Kehoe (1961) in ten normal subjects. The ratio of endogenous faecal to urinary clearance $(F / U)$ from $72 \mathrm{hr}$ after inhalation onwards was 0.6 . A ratio $F / U=0.8$ was found following injection of ${ }^{210} \mathrm{~Pb}$ in a baboon (Cohen, Wrenn and Eisenbud, 1971).

The total urinary plus endogenous faecal excretion therefore gave an average clearance rate of $7 \mathrm{ml} / \mathrm{hro}$ The average estimated blood volume of the subject was 4.8 litres. Making no allowance for exchangê of ${ }^{203} \mathrm{~Pb}$ between bone or other organs and blood, the decay constant for blood lead deduced from the excretion is

$$
\lambda=7 / 4800=1.5 \times 10^{-3} \mathrm{~h}^{-1} \cdot=0.035 \mathrm{~d}^{-1}
$$

and the corresponding half-life is 20 days in fair agreement with Fig. 4.

\section{Extrapolation to continuous exposure}

To apply the experimental results, it is of interest to extrapolate from short-term experiments to longterm exposure. If a person is exposed to $1 \mu \mathrm{g} / \mathrm{m}^{3}$ of airborne lead for $24 \mathrm{hr}$ a day, and breathes $15 \mathrm{~m}^{3} /$ day, and if $40 \%$ of the inspired aerosol is deposited in the lung, $50 \%$ of the lung burden is transferred to erythrocytes, the biological half-life in blood is $\mathbf{1 5}$ days, and the blood volume 5.4 litres (International Commission on Radiological Protection Report of Committee II (1959)) then blood lead will be raised by an amount $\alpha(\mu \mathrm{g} / 100 \mathrm{ml})$, where

$$
\alpha=\frac{15 \times 0.4 \times 0.5 \times 15}{54 \times 0.693}=1.2 .
$$

This calculation takes into account only the short term transfer to blood and assumes that the remaining $50 \%$ is transferred to bone and stored there. 
However, published epidemiological data do not appear to be inconsistent with $\alpha$ equal to about $1 \mu \mathrm{g} / 100 \mathrm{ml}$ per $\mu \mathrm{g} / \mathrm{m}^{3}$ in air, provided the air concentration is expressed as a $24 \mathrm{hr}$ average and is not interpreted from the maximum of observed environmental variations.

\section{References}

Azar, A., Snee, R.D. \& Habibi, K. (1972) Relationship of community levels of air lead and indices of lead absorption. In: Environmental Health Aspects of Lead, pp. 581-593, CID Luxembourg.

Booker, D.V., Chamberlain, A.C., Newton, D. \& Stott, A.N.B. (1969) Uptake of radioactive lead following inhalation and injection. British Journal of Radiology, 42, 457.

Clarkson, T.W. \& Kench, J.R. (1958) Uptake of lead by human erythrocytes in vitro. Biochemical Journal, 69, 432.

Cohen, N., WrenN, MC.D.E. \& EISENBUd, M. (1971) The retention and distribution of ${ }^{210} \mathrm{~Pb}$ in the adult baboon. New York University Medical Center. NYO-3086-11.

Cole, J.F. \& LYNAM, D.R. (1972) ILZRO's research to define lead's impact on man. In: Environmental Health Aspects of Lead, pp. 169-187, CID Luxembourg.

HuRSH, J.B. (1973) Retention of ${ }^{210} \mathrm{~Pb}$ in beagle dogs, Health Physics, 25, 29.
Hursh, J.B. \& Mercer, T.T. (1970) Measurement of ${ }^{212} \mathrm{~Pb}$ loss rate from human lungs. Journal of Applied Physiology, 28, 268.

Hursh, J.B., Schraub, A., Salter, E.L. \& Hofmann, H.P. (1969) Fate of ${ }^{212} \mathrm{~Pb}$ inhaled by human subjects. Health Physics, 16, 257.

International Commission on Radiological Protection. Report of Committee II (1959). Pergamon, Oxford.

Jones, R.D., Commins, B.T. \& Cernik, A.A. (1972) Blood lead and carboxyhaemoglobin levels in London taxi drivers. Lancet, ii, 302.

KEHOE, R.A. (1961) The metabolism of lead in man in health and disease. Journal of the Royal Institute of Public Health and Hygiene, 24, 81, 101, 129, 177.

Lawther, P.J., Commins, B.T., Ellison, J.Mc.K. \& Biles, B. (1972) Airborne lead and its uptake by inhalation. In: Lead in the Environment (ed. P. Hepple). Institute of Petroleum, London.

Rabinowitz, M.B., Wetherill, G.W. \& KopPle, J.D. (1973) Lead metabolism in the normal human: stable isotope studies. Science, $182,725$.

Stover, B.J. (1959) $\mathrm{Pb}^{212}$ (Thb) tracer studies in adult beagle dogs. Proceedings of the Society of Experimental Biology and Medicine, 100, 269.

Williams, M.K., KING, E. \& Walford, J. (1969) An investigation of lead absorption in an electric accumulator factory with the use of personal samplers. British Journal of Industrial Medicine, 26, 202. 